\title{
DETERMINAN TINGKAT KEMISKINAN DI PROVINSI DAERAH ISTIMEWA YOGYAKARTA
}

\author{
Yunia Arien Fairizta ${ }^{1}$ \\ Suharno ${ }^{2}$ \\ Nurul Anwar ${ }^{3}$ \\ Fakultas Ekonomi dan Binis Universitas Jenderal Soedirman, Purwokerto ${ }^{1,2,3}$ \\ Email: yuniaarienfairizta@gmail.com ${ }^{1,2,3}$
}

\begin{abstract}
The percentage of poor people in the Special Region of Yogyakarta Provinceis higher when compared to other provinces in Java Island. This study aims to analyze the effect of tourism sector, life expectancy, and the average length of schooling on poverty in the Special Region of Yogyakarta Province. The research method uses multiple linear regression with a panel data approach. The results showed that of tourism sector, life expectancy, and average length of schooling had a negative and significant effect on poverty in the Special Region of Yogyakarta Province in 2000-2019. These findings recommend the need for the development of the tourism sector that involves the participation of local communities. In addition, development of equitable education and health infrastructure to improve the quality of education and public health in the Special Region of Yogyakarta Province.
\end{abstract}

Keywords: Poverty; Tourism; life expectancy; education

\begin{abstract}
ABSTRAK
Persentase penduduk miskin di Provinsi Daerah Istimewa Yogyakarta besar tinggi bila dibandingkan dengan provinsi lain di Pulau Jawa. Penelitian ini bertujuan untuk menganalisis pengaruh sektor pariwisata, angka harapan hidup, dan rata-rata lama sekolah terhadap kemiskinan di Provinsi Daerah Istimewa Yogyakarta. Metode penelitian menggunakan regresi linier berganda dengan pendekatan data panel. Hasil penelitian menunjukkan bahwa pariwisata, angka harapan hidup, dan rata-rata lama sekolah berpengaruh negatif dan signifikan terhadap kemiskinan di Provinsi Daerah Istimewa Yogyakarta tahun 2000-2019. Temuan ini merekomendasikan perlunya pengembangan sektor pariwisata yang melibatkan partisipasi masyarakat setempat. Selain itu, pembangunan sarana prasarana pendidikan dan kesehatan yang berkeadilan untuk meningkatkan kualitas pendidikan dan kesehatan masyarakat di Provinsi Daerah Istimewa Yogyakarta.
\end{abstract}

Kata Kunci: Kemiskinan; Pariwisata; Angka Harapan Hidup; Pendidikan 


\section{PENDAHULUAN}

Kemiskinan seringkali dikaitkan dengan minimnya pendapatan, sehingga pemenuhan terhadap kebutuhan pokok menjadi sangat sulit bagi golongan masyarakat miskin. Kemiskinan menjadi suatu masalah yang sangat kompleks dimana untuk menanggulanginya harus menentukan solusi dan strategi yang tepat dan berkesinambungan (Ikejiaku, 2009). Ozughalu (2016) mengatakan bahwa kemiskinan menjadi tantangan bagi suatu negara dalam pembangunan dan pertumbumbuhan ekonomi. Tingginya angka kemiskinan menjadi salah satu faktor yang dapat menghambat pembangunan ekonomi suatu negara (Kuncoro, 2015). Dengan demikian, kemiskinan perlu diperhatikan secara khusus bagi seluruh negara untuk diatasi dan ditanggulangi.

Kuncoro (2015) dalam bukunya menyebutkan bahwa dari segi ekonomi, ada beberapa faktor yang dapat menyebabkan kemiskinan. Pertama, kapasitas sumber daya yang dimiliki oleh tiap individu maupun kelompok penduduk menunjukkan ketidaksamaan yang tinggi yang mengakibatkan ketimpangan dalam distribusi pendapatan. Penduduk golongan miskin cenderung mempunyai kepemilikan sumber daya yang terbatas dengan kualitas yang rendah. Kedua, kualitas sumber daya manusia yang timpang. Apabila sumber daya manusia yang dimiliki berkualitas rendah maka kecenderungan untuk melakukan kegiatan produksi juga akan rendah yang akhirnya hanya memiliki upah yang minim. Kualitas sumber daya manusia dapat dipengaruhi oleh beberapa hal seperti, 
pendidikan, kondisi lingkungan, sosial, dan keturunan. Ketiga, akses modal yang tidak tersebar secara merata.

Salah satu provinsi di Pulau Jawa yang persentase penduduk tertinggi adalah Daerah Istimewa Yogyakarta. Karateristik penduduk miskin di Provinsi Provinsi Daerah Istimewa Yogyakarta berkaitan dengan rendahnya tingakat pendidikan masyarakat dan perumahan yang tidak layak huni. Oleh karena itu, untuk mengurangi jumlah penduduk miskin di Provinsi Provinsi Daerah Istimewa Yogyakarta perlu dilakukan analisis lebih lanjut, guna mendapatkan informasi yang jelas yang dapat digunakan dalam merumuskan kebijakan.

Tabel 1.

Kemiskinan Berdasarkan Provinsi di Pulau Jawa Tahun 2015-2019 (\%)

\begin{tabular}{|c|c|c|c|c|c|c|}
\hline \multirow{2}{*}{ No } & \multirow{2}{*}{ Provinsi } & \multicolumn{5}{|c|}{ Tahun } \\
\hline & & 2015 & 2016 & 2017 & 2018 & 2019 \\
\hline 1 & DI Yogyakarta & 13,22 & 12,69 & 11,97 & 13,99 & 11,57 \\
\hline 2 & Jawa Tengah & 13,23 & 12,62 & 11,26 & 13,61 & 10,69 \\
\hline 3 & Jawa Timur & 11,95 & 11,48 & 10,92 & 11,98 & 10,29 \\
\hline 4 & Jawa Barat & 8,86 & 8,27 & 7,35 & 7,45 & 6,87 \\
\hline 5 & Banten & 5,39 & 5,52 & 5,25 & 5,57 & 5,02 \\
\hline 6 & DKI Jakarta & 3,75 & 3,76 & 3,56 & 3,74 & 3,45 \\
\hline
\end{tabular}

Dalam mendorong atau menopang pertumbuhan ekonomi di Provinsi Daerah Istimewa Yogyakarta, sektor pariwisata memiliki peran yang cukup besar. Sektor pariwisata merupakan sektor penggerak perekonomian di Provinsi Daerah Istimewa Yogyakarta, hal tersebut dikarenakan sektor pariwisata memiliki efek pengganda (multiplier effect). Sektor pariwisata di Provinsi Daerah Istimewa Yogyakarta dapat mengerakkan sektor-sektor perekonomian lainnya seperti industri, perhotelan, makanan, akomodasi \& jasa transportasi dan sektor perekonomian lain sebagainya. Dengan adanya multiplier effect dari sektor 
pariwisata maka akan memiliki dampak yang signifikan terhadap pertumbuhan ekonomi, mengurangi jumlah penggangguran dan penduduk miskin.

Beberapa studi empiris seperti (Bryden, 1973; Saayman at al. 2012; Njoya \& Seetaram, 2018; dan Garza-rodriquez, 2019) menjelaskan bahwa sektor pariwisata memiliki hubungan yang erat dengan perumbuhan ekonomi dalam mengurangi jumlah penduduk miskin. Temuan Ashley et al. (2001) menjelaskan bahwa pariwisata merupakan sektor yang sangat efektif dalam mengurangi jumlah penduduk miskin di suatu daerah. Sektor pariwisata mampu menciptakan kesempatan kerja, meningkatkan pendapatan dan kesejahteraan masyarakat, dan jumlah penduduk miskin akan berkurang (Spenceley \& Seif, 2003).

Sejalan dengan temuan Njoya \& Seetaram (2018) yang menganalisis pengaruh pariwisata terhadap kemiskinan di Kenya yang menemukan bahwa dalam kurun waktu 20 tahun peningkatan aktivitas pariwisata mampu menurunkan jumlah penduduk miskin (1,84 persen). Namun demikian dalam temuanya menjelaskan bahwa terdapat beberapa hal yang dapat menghambat pengaruh pariwisata terhadap pengentasan kemiskinan, yaitu jaminan kerja yang tidak memadai bagi pekerja perusahaan pariwisata skala besar, kurang dukungan dari pemerintah terhadap perusahaan pariwisata berskala kecil, dan mayoritas peran pekerja hanya sebagai karyawan pemilik dan pengembang pariwisata.

Berbeda halnya dengan temuan (Jamieson at al. 2018 dan Roy, 2018) yang menjelaskan bahwa sektor pariwisata belum mampu menurunkan jumlah penduduk miskin secara signifikan, masih perlu banyak dukungan studi empiris, teori, dan konsep ekonomi untuk menjelaskan pengaruh pariwisata terhadap 
penurunan jumlah penduduk miskin. Selain itu, temuan Mbaiwa (2005) menemukan bahwa sektor pariwisata tidak memiliki kontribusi yang nyata terhadap pengentasan penduduk miskin. Hal tersebut dikarenakan sektor pariwisata didominasi oleh investasi asing, seingga posisi strategis pada sektor pariwisata hanya ditempati oleh penduduk asing sementara penduduk lokal yang bekerja dengan tingkat pendapatan yang lebih rendah.

Selain itu kemiskinan juga memiliki hubungan erat dengan kualitas suber daya manusia yang dapat diproksi dari Angka Harapan Hidup (AHH) dan rata-rata lama sekolah di suatu wilayah. Wyk \& Bradshaw (2019) menjelaskan apabila kesehatan masyarakat yang diukur dengan Angka Harapan Hidup (AHH) memiliki nilai yang tinggi, maka akan memberikan kesempatan untuk meningkatkan pendapatan yang lebih tinggi. Ataguba et al. (2013) berpendapat bahwa kesehatan menjadi salah satu faktor untuk menurunkan kemiskinan.

Suatu negara yang memiliki standar atau kualitas kesehatan yang baik memiliki angka harapan hidup yang lebih tinggi, sehingga semkian tinggi angka harapan hidup akan berpeluang untuk memperoleh pendapatan tinggi dan kehidupan yang layak. Selain itu, Ataguba et al. (2013) berpendapat bahwa tingkat kemiskinan yang menurun dapat disebabkan salah satunya adalah karena pendidikan. Menurut Sanz et al. (2017) pendidikan sangat memungkinkan untuk mempengaruhi kemiskinan. Dalam penelitian Bakhtiari \& Meisami (2009) pendidikan berpengaruh negatif dan signifikan terhadap kemiskinan. Masyarakat dengan pendidikan yang rendah cenderung lebih sulit untuk meningkatkan pendapatan yang lebih tinggi sehingga masyarakat golongan miskin yang 
memiliki keterbatasan dalam mengakses pendidikan akan terus terjerat dalam kemiskinan.

Hal yang melatarbelakangi penelitian ini adalah persentase penduduk miskin di Provinsi Daerah Istimewa Yogyakarta tertinggi di Pulau Jawa. Selain itu, adanya temuan yang bertentangan mengenai pengaruh sektor pariwisata terhadap kemiskinan, sehingga keterbaharuan penelitian ini adalah perlunya dikaji kembali mengenai pengaruh sektor pariwisata terhadap kemiskinan. Dengan demikian penelitian ini bertujuan menganalisis pegaruh sektor pariwisata, angka harapan hidup, dan pendidikan terhadap kemiskinan di Provinsi Daerah Istimewa Yogyakarta pada tahun 2000-2019.

\section{METODE PENELITIAN}

Penelitian ini termasuk dalam jenis penelitian kuantitatif, dimana data yang digunakan bersumber dari Badan Pusat Statistik (BPS) Provinsi Daerah Istimewa Yogyakarta. Secara purposive sampling penelitian ini mengambil lokasi penelitian di Provinsi Daerah Istimewa Yogyakarta, hal tersebut dikarenakan Provinsi Daerah Istimewa Yogyakarta merupakan provinsi dengan persentase penduduk miskin tertinggi di Pulau Jawa (dilihat pada Tabel 1). Teknik analisis yang digunakan adalah teknik analisis regresi linier berganda dengan model regresi data panel. Data panel merupakan data gabungan dari data cross section dan time series (Gujarati \& Porter, 2009). Dalam penelitian ini data cross section adalah 5 kabupaten kota di Provinsi Daerah Istimewa Yogyakarta yang meliputi Kota Yogyakarta, Kabupaten Sleman, Bantul, Kulonprogo, dan Gunung Kidul, sedangkan data time seriesnya adalah dari tahun 2000 sampai dengan 2019. 
Periode penelitian dari tahun 2000 sampai dengan 2019 didasarkan karena ketersedian data di tingkat kabupaten yang tidak tersedia, sehingga hanya dapat menggunakan tahun penelitian selama 20 tahun untuk time seriesnya.

Kemiskinan adalah variabel dependen dalam penelitian ini yang didefinisikan sebagai jumlah penduduk miskin yang diukur dalam satuan persentase. Sementara itu variabel independen yang digunakan dalam penelitian ini adalah 1) pariwisata yang diartikan dari jumlah wisatawan mancanegara dan domestik yang diukur dengan satuan jiwa, 2) angka harapan hidup adalah rata-rata perkiraan banyaknya tahun yang akan ditempuh seseorang yang diukur dengan satuan tahun, dan 3) rata-rata lama sekolah adalah rata-rata sekolah yang ditamatkan yang diukur degan satuan tahun.

Dasar penggunaan variabel independen dalam penelitian ini adalah sektor pariwisata di Provinsi Daerah Istimewa Yogyakarta merupakan sektor yang perkembangnya sangat pesat. Selain itu jika dilihat dari Human Development Index Provinsi Daerah Istimewa Yogyakarta menempati posisi kedua setelah Provinsi DKI Jakarta, namun jika ditinjau dari angka harapan hidup Provinsi Daerah Istimewa Yogyakarta menempati posisi pertama jika dibandingkan dengan semua provinsi di Indonesia. Berikut ini adalah persamaan regresi liner berganda dengan model data panel yang digunakan daam penelitian ini.

$$
Y_{i t}=\alpha+\beta_{1} L n P W R_{1 i t}+\beta_{2} L n A H H_{2 i t}+\beta_{3} R R L S_{3 i t}+\mu_{i}
$$

Keterangan:

$$
\begin{array}{ll}
\mathrm{Y} & =\text { Kemiskinan } \\
\alpha & =\text { Konstanta } \\
\beta_{1,2,3} & =\text { Koefisien regresi } \\
P W R_{1} & =\text { Pariwisata }
\end{array}
$$




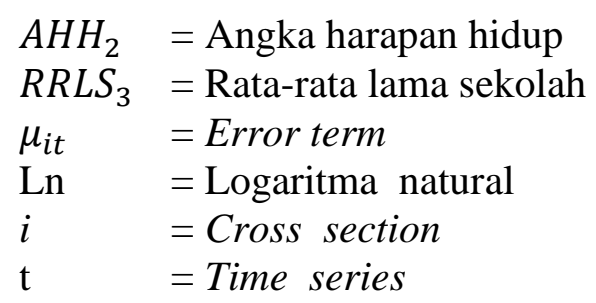

Dari tiga model yang terdapat pada regresi data panel hanya dapat dipilih satu model yang dapat digunakan diantara common effect model, fixed effect model, dan random effect model. Untuk menentukan model yang digunakan maka perlu dilakukan Uji Chow, Uji Hausman, dan Uji LM (Gujarati \& Porter, 2009). Setelah mendapatkan model regresi yang terbaik langkah selanjutnya adalah mendeteksi apakah model yang digunakan sudah memenuhi standar Best Linier Unbias Estimator (BLUE). Output regresi linier berganda yang bersifat BLUE harus memenuhi syarat uji normalitas, heteroskedastisitas, multikolinearitas, dan autokorelasi, sehingga dapat disumsikan bahwa model yang digunakan baik atau tidak (Gujarati \& Porter, 2009).

\section{HASIL DAN PEMBAHASAN}

Berdasarkan hasil penelitian output regresi yang dapat di estimasi dalam penelitian ini adalah common effect model dan fixed effect model. Sementara itu itu, random effect model tidak dapat di estimasi, hal tersebut dikarenakan jumlah cross section tidak lebih banyak dari variabel bebas yang digunakan dalam penelitian (Gujarati \& Porter, 2009). Dengan demikian dalam penelitian ini hanya menggunakan uji chow dalam menentukan pemilihan model, sementara itu uji Hausman dan uji Lagrange Multiplier tidak perlu untuk dilakukan. Langkah selanjutnya adalah membandingkan common effect model dengan fixed effect 
model untuk menentukan model manakah yang layak untuk digunakan dalam penelitian ini dengan menggunakan uji Chow. Berikut ini Tabel 2 yang menunjukkan hasil pemeilihan midel menggunakan uji Chow dan uji Hausman.

Tabel 2.

Ringkasan Uji Chow dan Uji Hausman

\begin{tabular}{|c|c|c|c|c|}
\hline \multirow{2}{*}{ No } & \multicolumn{2}{|c|}{ Uji Chow } & \multicolumn{2}{|c|}{ Uji Hausman } \\
\hline & Effects Test & P-Value & Test Summary & P-Value \\
\hline 1 & Cross-section Chi-square & 0,0000 & Cross-section random & 0,0042 \\
\hline
\end{tabular}

Berdasarkan uji Chow menunjukkan bahwa nilai p-value cross section chi-square sebesar 0,0000. Nilai tersebut lebih kecil jika dibandingkan dengan taraf signifikansi 0,05 persen, sehingga berdasarkan uji Chow model regresi yang digunakan adalah fixed effect model. Sementara itu, dari uji Hausman menunjukkan bahwa nilai Cross-section random sebesar 0,0042. Nilai tersebut lebih kecil dari pada jika dibandingkan dengan taraf signifikansi 0,05 persen, sehingga model yang digunakan dalam penelitian ini adalah fixed effect model.

Pada prinsinya hasil regresi linier berganda harus bersifat Best Linier Unbias Estimator (BLUE) agar dapat diketahui apakah model yang digunakan dalam penelitian merupakan model yang terbaik atau tidak. Uji yang digunakan dalam regresi linier berganda agar model bersifat BLUE adalah uji normalitas, heteroskedastisitas, multikolinearitas, dan autokorelasi. Uji normalitas digunakan untuk mendeteksi apakah dalam model regresi yang digunakan data dari variabel dependen dan independen terdistribusi normal atau tidak (Gujarati \& Porter, 2009). Berdasarkan uji jarque bera menghasilkan nilai $\mathrm{p}$ value sebesar 0,8736 . Nilai tersebut lebih besar jika dibandingkan dengan taraf signifikansi 0,05 persen, sehingga data dalam penelitian ini terdistribusi normal. 
Untuk mengetahui apakah terjadi ketidaksamaan varian dari residual untuk semua pengamatan pada regresi linier. Uji heteroskedastisitas dapat dilakukan dengan menggunakan metode uji park. Suatu penelitian dinyatakan bebas dari heteroskedastisitas apabila nilai $p$ value dari setiap variabel independen dari uji park lebih besar dari pada taraf signifikansi 0,05 persen. Dalam penelitian ini dapat dinyatakan bebas dari heteroskedastisitas karena nilai $p$ value setiap variabel independen lebih besar dari taraf signifikansi. Untuk mengetahui nilai $p$ value setiap variabel dapat dilihat pada Tabel 3 yang menunjukkan ringkasan dari uji hetoreskedastisitas menggunakan metode uji park.

Tabel 3.

Hasil Uji Hetoreskedastisitas

\begin{tabular}{clc}
\hline No & \multicolumn{1}{c}{ Variabel } & $p$-value \\
\hline 1 & Pariwisata & 0,7653 \\
2 & Angka Harapan Hidup & 0,2436 \\
3 & Rata-rata Lama Sekolah & 0,5241 \\
\hline Sumber: & data diolah, 2020
\end{tabular}

Uji selanjutnya adalah multikolinearitas. Uji tersebut digunakan untuk mendeteksi apakah terjadi hubungan atau korelasi antara variabel independen atau tidak. Untuk mengidentifikasi apakah dalam model penelitian terjadi multikolinearitas dapat dilakukan uji Variance Inflation Factor (VIF) dengan kriteria pengujian apabila nilai VIF setiap variabel bebas kurang dari 10 maka dapat dikatakan bebas dari multikolinearitas (Suliyanto, 2011). Tabel 4 menunjukkan hasil uji multikolinearitas.

Tabel 4.

Hasil Uji Multikolinearitas

\begin{tabular}{clc}
\hline No & \multicolumn{1}{c}{ Variabel } & Nilai VIF \\
\hline 1 & Pariwisata & 1,448912 \\
2 & Angka Harapan Hidup & 1,114309 \\
3 & Rata-rata Lama Sekolah & 1,075465 \\
\hline Sumber: & data diolah, 2020
\end{tabular}

Sumber: data diolah, 2020 
Dalam penelitian ini dapat disimpulkan terbebas dari multikolinearitas karena nilai VIF disetiap variabel independen kurang dari 10. Uji terakhir yang dilakukan adalah uji autokorelasi. Uji tersebut digunakan untuk mendeteksi apakah dalam model regresi linier berganda terdapat korelasi antara kesalahan pada periode atau waktu dengan kesalahan pengganggu pada ruang atau waktu sebelumnya. Untuk mengetahui suatu penelitian terdapat autokorelasi atau tidak dapat dilakukan dengan uji Durbin-Watson. Nilai DW dalam penelitian ini adalah 1,7534 dan nilai DL sebesar 1,4563 serta nilai dU sebesar 1,6615. Nilai tersebut masuk dalam kriteria pengujian $\mathrm{dU}<\mathrm{d}<4-\mathrm{dU}$, sehingga dapat dikatakan bahwa dalam penelitian ini bebas dari autokorelasi.

Seletah melewati uji kecocokan model dan fixed effect model yang terpilih serta sudah dinyatakan BLUE, sehingga output regresi fixed effect model dapat diringkas seperti yang tertera pada Tabel 5.

Tabel 5.

Ringkasan Regresi Fixed Effect Model.

\begin{tabular}{llccc}
\hline \multicolumn{1}{c}{ Variabel } & Koefisien & T-Statistik & T-Tabel & P-Value \\
\hline Pariwisata & $-2,9203$ & $-3,6876$ & 1,98373 & 0,0007 \\
Angka Harapan Hidup & $-0,0648$ & $-3,4928$ & 1,98373 & 0,0012 \\
Rata-rata Lama Sekolah & $-1,1958$ & $-2,6161$ & 1,98373 & 0,0125 \\
\hline Konstanta & 19,6251 & & & \\
Adjusted $R$-Squared & 0,6352 & & & \\
F-Statistik & 16,3762 & & & \\
\hline Sumber & & &
\end{tabular}

Sumber: data diolah, 2020

Nilai koefisien pariwisata sebesar $-2,9203$ dan nilai $p$ value 0,0007 . Hal tersebut menunjukkan bahwa pariwisata signifikan berpengaruh negatif terhadap kemiskinan di Provinsi Daerah Istimewa Yogyakarta. Temuan ini sejalan dengan Njoya \& Seetaram (2018) yang menemukan bahwa sektor pariwisata dapat menurunkan jumlah penduduk miskin di negara Kenya. Temuannya menjelaskan 
bahwa pengembangan sektor pariwisata akan memiliki dampak atau menguntungkan sektor perekonomian lainnya, sehingga akan terjadi sinergi antara sektor-sektor perekonomian dan berdampak pada penurunan jumlah peduduk miskin di Negara Kenya. Sektor pariwisata mampu menciptakan kesempatan kerja baru, meningkatkan pendapatan masyarakat dan kesejahteraan masyarakat, serta jumlah penduduk miskin akan berkurang (Spenceley \& Seif, 2003; Guoqing \& Yang, 2012; dan Yang \& Hung, 2014).

Menurut Ucceli (1997) menjelaskan bahwa sektor pariwisata khususnya perhotelan dapat mengurangi jumlah penduduk miskin. Temuannya menjelaskan bahwa sektor pariwisata akan membentuk trickle down effect, dimana sektor pariwisata khususnya sektor perhotelan mampu menciptakan peluang ekonomi bagi masyarakat khususnya dalam penyediaan lapangan pekerjaan baru. Sejalan dengan temuan Anwar (2012) dalam penelitianya menemukan bahwa pariwisata berpengaruh signifikan terhadap meningkatkan perekonomian penduduk miskin di Negara Bangladesh, selain itu sektor pariwisata dapat mempertahankan nilai-nilai kebudayaan lokal dari asing, dan sektor pariwisata mampu meningkatkan pendapatan dan kesejahteraan masyarakat.

Provinsi Daerah Istimewa Yogyakarta merupakan provinsi dengan jumlah wisatawan mancanegara maupun domestik cukup banyak. Provinsi Daerah Istimewa Yogyakarta memiliki visi pada tahun 2012-2025 yaitu menjadika Provinsi Daerah Istimewa Yogyakarta menjadi destinasi wisatawan yang berkelas dunia, memiliki daya saing, memiliki wawasan kebidayaan, berkelanjutan, serta mampu menopang pembangunan daerah dan berorientasi pemberdayaan 
masyarakat. Sejalan dengan hal tersebut pemerintah daerah Provinsi Daerah Istimewa Yogyakarta mengembangkan community based tourism (CBT) yag diharapkan dapat menekan jumlah penduduk miskin dikawasan perkotaan dan perdesaan. Diharapkan dengan adanya CBT tersebut bertujuan untuk menggerakkan semua sektor perekonomian khususnya sektor pariwisata, sehingga akan berdampak pada terciptanya lapangan pekerjaan baru seperti perdagangan, industri, dan sektor jasa lainnya.

Sejalan dengan visi Provinsi Daerah Istimewa Yogyakarta temuan Ashley et al. (2001) yang menganalisis strategi pro poor tourism (PPT) di beberapa negara di Benua Afrika, yang menemukan bahwa staretegi PPT sangat efektif dan signifikan dalam mengurangi jumlah penduduk miskin. Selain itu, strategi PPT tersebut memiliki dampak yang signfikan juga terhadap terciptanya kesempatan kerja baru, mengurangi ketimpangan pendapatan, dan meningkatkan kesejahteraan masyarakat, serta berdampak langsung terhadap bertambahnya kegiatan usaha berskala mikro.

Nilai koefisien angka harapan hidup sebesar $-0,0648$ dan nilai $p$ value 0,0012. Hal tersebut menunjukkan bahwa angka harapan hidup signifikan berpengaruh negatif terhadap kemiskinan di Provinsi Daerah Istimewa Yogyakarta. Sejalan dengan temuan ini Dores \& Jolianis (2014) juga menemukan bahwa angka harapan hidup di Provinsi Sumatra Barat berpengaruh negatif terhadap kemiskinan, artinya ketika angka harapan hidup meningkat dapat mengurangi jumlah penduduk miskin di Provinsi Sumarta Barat. Temuan Dores \& Jolianis (2014) menjelaskan bahwa semakin lama angka harapan hidup di suatu 
daerah diharapkan mampu meningkatkan kesejahteraan dan jumlah penduduk miskin berkurang. Ataguba et al. (2013) berpendapat bahwa kesehatan menjadi salah satu faktor untuk menurunkan kemiskinan.

Negara satu suatu daerah yang memiliki standar atau kualitas kesehatan yang cukup baik akan memiliki angka harapan hidup yang lebih tinggi, sehingga semakin tinggi angka harapan hidup akan berpeluang untuk memperoleh pendapatan tinggi dan kehidupan yang layak. Wyk \& Bradshaw (2019) menjelaskan apabila kesehatan masyarakat yang diukur dengan Angka Harapan Hidup (AHH) memiliki nilai yang tinggi, maka akan memberikan kesempatan untuk meningkatkan pendapatan yang lebih, tinggi. Menurut Purnomo et al. (2019) menjelaskan bahwa angka harapan hidup dapat mendorong penduduk untu berinovasi, bekerja lebih lama dan dapat meningkatkan output serta pendapatan.

Provinsi Daerah Istimewa Yogyakarta adalah provinsi dengan angka harapan hidup tertinggi yaitu 73,13 tahun. Nilai tersebut lebih tinggi jika dibandingkan dengan angka harapan hidup secara nasional yaitu 69,44 tahun. Angka harapan hidup tersebut harus selalu ditingkatkan karena dapat berpengaruh secara langsung maupun tidak langsung terhadap pengurangan jumlah penduduk miskin secara umum. Menurut Mariyanti \& Mahfudz (2019) dalam bidang kesehatan, jika konsumsi nutrisi buruk maka akan berdampak terhadap jumlah penduduk miskin, sehingga negara dengan penduduk yang memiliki kualitas kesehatan yang baik, secara rata-rata penduduk di negara tersebut akan bertahan hidup yang lebih lama. 
Hal tersebut dikarenakan secara ekonomi penduduk yang memiliki usia hidup yang lebih panjang akan memiliki peluang untuk mendapatkan pendapatan yang lebih besar dan taraf kehidupan yang lebih baik. Oleh karena itu, dengan adanya peran pemerintah dalam memperbaiki kualitas kesehatan suatu daerah akan memiliki dampak secara langsung terhadap pengurangan jumah penduduk miskin. Temuan Bakhtiari \& Meisami (2009) menemukan bahwa dengan adanya peningkatan kualitas kesehatan akan berdampak pada daya kerja, serta dapat mengurangi hari yang tidak digunakan dalam berkerja, serta dapat meningkatkan output energy secara umum, sehingga akan berkorelasi terhadap pengurangan jumlah penduduk miskin.

Nilai koefisien rata-rata lama sekolah sebesar -1,1958 dan nilai $p$ value 0,0125. Hal tersebut menunjukkan bahwa rata-rata lama sekolah signifikan berpengaruh negatif terhadap kemiskinan di Provinsi Daerah Istimewa Yogyakarta. Temuan ini sejalan dengan (Purnomo at al. 2020; Purnomo \& Istiqomah, 2019; dan Purnomo, 2019) yang menemukan bahwa pendidikan yang dalam penelitiannya diproksi dari rata-rata lama sekolah signifikan berpengaruh negatif terhadap kemiskinan. Selain itu, menurut Tarabini \& Jacovkis (2012) semakin tinggi tingkat pendidikan seseorang maka akan berpeluang dalam mendapatkan perkerjaan yang lebih baik dan memiliki pendapatan yang layak.

Menurut Doshi (2020) pendidikan memiliki pengaruh secara langsung terhadap kemiskinan melalui meningkatknya produktivitas penduduk miskin, kesempatan yanng lebih besar dalam mendapatkan pekerjaan dengan imbalan yang lebih besar. Namun demikian jika ditinjau dari rata-rata lama sekolah pada 
tahun 2019 Provinsi Daerah Istimewa Yogyakarta yaitu 9,92 tahun. Akan tetapi jika ditinjau dari kabupaten/kota di tahun yang sama rata-rata, lama sekolah tertinggi adalah Kota, Yogyakarta (11,41 tahun), posisi kedua Kabupaten Sleman (10,77 tahun), posisi ketiga Kabupaten Bantul (9,55 tahun), posisi keempat Kabupaten Kulonprogo (8,69 tahun), dan posisi kelima adalah Kabupaten Gunung Kidul (7,17 tahun) dan jika dibandingkan dengan rata-rata lama sekolah Indonesia (8,75 tahun) Provinsi Daerah Istimewa Yogyakarta masih lebih baik.

Temuan ini juga sejalan dengan Bakhtiari \& Meisami (2009) yang menemukan bahwa pendidikan memiliki korelasi terhadap penurunan jumah penduduk miskin. Untuk mengurangi jumlah penduduk miskin tentu diperlukan pendidikan yang berkualitas (Hindun, 2019). Menurut Todaro \& Smith (2012) pendidikan formal merupakan salah satu modal manusia yang sangat krusial dalam pembangunan. Semakin mudahnya penduduk dalam mengakses fasilitas pendidikan, maka peluang dalam meningkatkan kesejahteraan semakin besar. Menurut Purnomo (2019) penduduk yang memiliki pendidikan yang semakin tinggi akan memiliki kemungkinan terjerat dalam lingkaran kemiskinan.

\section{SIMPULAN DAN SARAN}

Persentase penduduk miskin di Provinsi Daerah Istimewa Yogyakarta lebih tinggi jika dibandingkan dangan provinsi lainnya di Pulau Jawa. Angka kemiskinan di Provinsi Daerah Istimewa Yogyakarta tersebar diseluruh wilayah, namun yang menjadi kantong kemiskinan adalah daerah perdesaan. Selain itu Provinsi Daerah Istimewa Yogyakarta merupakan provinsi dengan kunjungan wisatawan yang cukup signifikan. Sektor Pariwisata di Provinsi Daerah Istimewa 
Yogyakarta memiliki karakter yang beragam mulai dari segi budaya, alam, dan wisata buatan yang tersebar di semua wilayah baik di perkotaan maupun perdesaan. Hasil penelitian menemukan bahwa sektor pariwisata berpengaruh negatif dan signifikan terhadap kemiskinan di Provinsi Daerah Istimewa Yogyakarta tahun 2000-2019, dengan nilai koefisien regresi sektor pariwisata sebesar -2,9203 dan nilai $p$ value 0,0007. Hal tersebut menunjukkan bahwa ketika wisatawan macanegara dan domestik meningkat dapat menurunkan jumlah penduduk miskin. Angka harapan hidup berpengaruh negatif dan signifikan terhadap kemiskinan di Provinsi Daerah Istimewa Yogyakarta tahun 2000-2019, dengan nilai koefisien regresi angka harapan hidup sebesar $-0,0648$ dan nilai $p$ value 0,001. Hal ini menunjukkan ketika angka harapan hidup meningkat dapat menurunkan jumlah penduduk miskin. Selain itu, rata-rata lama sekolah signifikan berpengaruh negatif terhadap kemiskinan di Provinsi Daerah Istimewa Yogyakarta tahun 2000-2019, dengan nilai koefisien regresi rata-rata lama sekolah sebesar $-1,1958$ dan nilai $p$ value 0,0125 . Hal ini menunjukkan bahwa terjadinya peningkatakan rata-rata pendidikan maka dapat mengurangi jumlah penduduk miskin di Provinsi Daerah Istimewa Yogyakarta.

Temuan ini merekomendasikan perlunya pengembangan sektor pariwisata yang melibatkan partisipasi masyarakat lokal. Selain itu, perlunya perhatian khusus dari pemerintah seperti pembangunan infrastruktur pendidikan dan kesehatan dalam meningkatkan pendidikan dan kualitas kesehatan masyarakat di Provinsi Daerah Istimewa Yogyakarta. Saran untuk penelitian selanjutnya yaitu biasa menganslisis sektor-sektor perekonomian lainnya yang dikaitkan dengan 
kemiskinan, sehingga dapat mengidentifikasi dan merumuskan kebijakan dalam mengurangi angka kemiskinan dari berbagai sudut pendang sektor perekonomian . Selain itu, dapat melakukan penelitian dengan lokasi yang lebih luas dan sempel lebih banyak atau membandingkan kinerja sektor pariwisata terhadap kemiskinan dengan provinsi lainnya.

\section{REFERENSI}

Anwar, J, M. (2012). Poverty Alleviation Through Sustainable Tourism: A Critical Analysis Of 'Pro-Poor Tourism' And Implications For Sustainability In Bangladesh. Research Report Presented to Professor COOPER Malcolm J. M. In Partial Fulfillment of the Requirements for the Degree Of Master of Science in International Cooperation Policy. 2(1). 194.

Ashley, C., Roe, D., \& Goodwin, H. (2001). Pro Poor Report No. 1 Pro-Poor Tourism Strategies: Making Tourism Work For The Poor. Overseas Development Institute.

Ataguba, J. E., Ichoku, H. E., \& Fonta, W. M. (2013). Multidimensional poverty assessment: applying the capability approach. International Journal of Social Economics, 40(4): 331-354.

Bakhtiari, S., \& Meisami, H. (2010). An empirical investigation of the effects of health and education on income distribution and poverty in Islamic countries. International Journal of Social Economics, 37(4), 293-301.

Bryden, J. (1973). Tourism and Development: A Case Study of the Commenwealth Carribean.

Dores, E., \& Jolianis, J. (2014). Pengaruh Angka Melek Huruf Dan Angka Harapan Hidup Terhadap Jumlah Penduduk Miskin Di Propinsi Sumatera Barat, Journal of Economic and Economic Education 2(2): 126-133.

Doshi, K. P. (2000). Growth and Inequality of Income. University of San Diego. Garza-Rodriguez, J. (2019). Tourism and poverty reduction in Mexico: An ARDL cointegration approach. Sustainability, 11(3): 1-11.

Gujarati, D. N., \& Porter, D. C. (2009). Basic Econometric 5th Edition. McGraw -Hill: New York.

Guoqing, H., \& Yang, Z. (2012). Research on tourism poverty alleviation model 
of reservoir region. International Conference on Information and Business Intelligence, 3(3). 603-608.

Hidun, P. (2019). Pengaruh Pendidikan, PDRB, Angkatan Kerja Terhadap Kemiskinan di Jawa Timur Tahun 2017. Media Trend 14(2): 186-193.

Ikejiaku, B. (2009). The Concept 'Poverty' towards Understanding in the Context of Developing Countries 'Poverty qua Poverty': with Some Comparative Evidence on Britain. Journal of Sustainable Development, 2(2): 3-13.

Jamieson, W., Goodwin, H., \& Edmunds C. (2004). Contribution of Tourism To Poverty Alleviantion: Pro-Poor Tourism and Challenge of Measuring Impacts. For Transport Policy and Tourism Section Transpor and Tourism Devision UN ESCAP.

Kuncoro, M. (2015). Otonomi Daerah: Menuju Era Baru Pembangunan Daerah. Jakarta: Erlangga.

Mariyanti, T., \& Mahfudz, A. A. (2016). Dynamic circular causation model in poverty alleviation: Empirical evidence from Indonesia. Humanomics, 32(3): 275-299.

Mbaiwa, J. E. (2005). Enclave tourism and its socio-economic impacts in the Okavango Delta, Botswana. Tourism Management, 1(26): 157-172.

Njoya, E. T., \& Seetaram, N. (2018). Tourism contribution to poverty alleviation in Kenya: A dynamic computable general equilibrium analysis. Journal of Travel Research, 57(4), 513-524.

Ozughalu, U. M. (2014). Relationship Between Household Food Poverty and Vulnerability to Food Poverty: Evidence from Nigeria. Social Indicators Research . 125(5). 567-587.

Purnomo, S. D., Istiqomah, I., \&; Suharno, S. (2020). The Effect of Human Capital and Human Capital Spillover on Economic Growth, International Conference on Rural Development and Enterpreneurship 2019 : Enhancing Small Busniness and Rural Development Toward Industrial Revolution 4.0. 5(1). 518-524.

Purnomo, S. D. (2019). Determinan Kemiskinan di Provinsi Daerah Istimewa Yogyakarta. AL-Amwal: Jurnal Ekonomi dan Perbankan Syari'ah, 11 (1): 47-58

Purnomo, S. D., Istiqomah, I., \&; Suharno, S. (2020). Hubungan Pendidikan Dan Kemiskinan: Pendekatan Variabel Mediasi Pendapatan Per Kapita. EJurnal Ekonomi dan Bisnis Universitas Udayana, 9(6): 539-560. 
Roy, H. (2010). Social Science Reasearch Network. The Role of Tourism to Poverty Alleviation.

Saayman, M., Rossouw, R., \& Krugell, W. (2012). The impact of tourism on poverty in South Africa. Development Southern Africa, 29(3): 462-487.

Sanz, R., Peris, J. A., \& Escámez, J. (2017). Higher education in the fight against poverty from the capabilities approach: The case of Spain. Journal of Innovation \& Knowledge, 2(2): 53-66.

Spenceley, A., \& Seif, J. (2003). Strategies, Impacts and Costs of Pro-Poor Tourism Approaches in South Africa. International Centre for Responsible Tourism, PPT Working Paper, 4(11). 1-44.

Suliyanto, S. (2011). Ekonometrika Terapan : Teori dan Aplikasi dengan SPSS. Yogyakarta: Penerbit Andi Offset.

Tarabini, A., \& Jacovkis, J. (2012). The Poverty Reduction Strategy Papers: An Analysis of a Hegemonic Link Between Education and Poverty. International Journal Of Educational Development. 32(4). 507-516.

Todaro, M. P., \& Smith, S. C. (2012). Economic Development (11 thed). New York: Pearson.

Uccelli, F, A. (1997). Poverty Alleviation in Peru: The Search for Sustainable Social Development, For delivery at the XX International Congress of the Latin American Studies Association Guadalajara, Mexico.

Wyk, V. P., \& Bradshaw, D. (2017). Mortality and socioeconomic status: the vicious cycle between poverty and ill health. The Lancet Global Health, 5(9).851-852.

Yang, X., \& Hung, K. (2014). Poverty alleviation via tourism cooperatives in China: the story of Yuhu. International Journal of Contemporary Hospitality Management, 26(6). 879-906. 